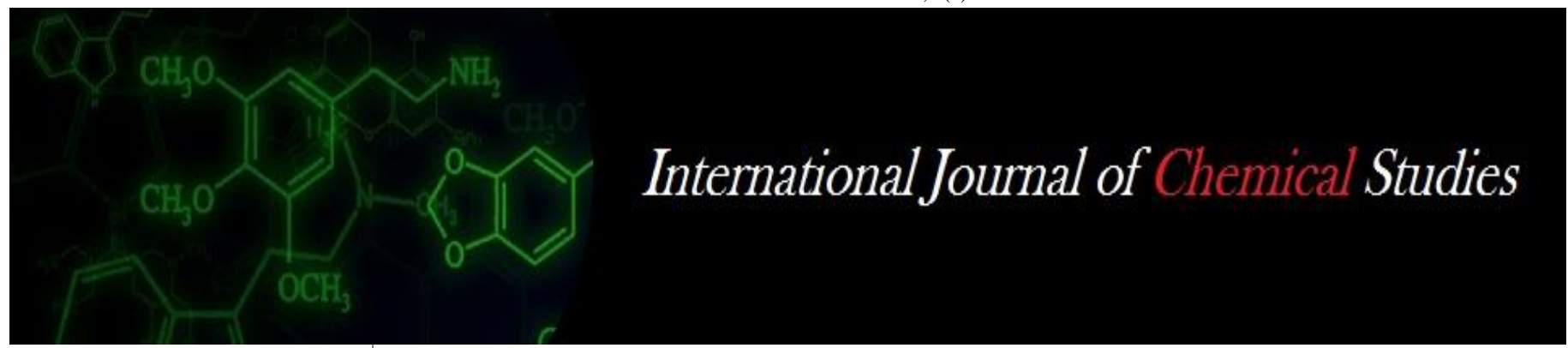

P-ISSN: 2349-8528

E-ISSN: 2321-4902

www.chemijournal.com

IJCS 2020; 8(3): 337-339

(C) 2020 IJCS

Received: 13-03-2020

Accepted: 15-04-2020

\section{Shital Bhagve}

Horticulture Section, College of Agriculture, Amravati Road,

Nagpur, Maharashtra, India

\section{VU Raut}

Horticulture Section, College of Agriculture, Amravati Road

Nagpur, Maharashtra, India

\section{Neha Chopde}

Horticulture Section, College of Agriculture, Amravati Road,

Nagpur, Maharashtra, India

\section{VP Satar}

Horticulture Section, College of Agriculture, Amravati Road, Nagpur, Maharashtra, India

Corresponding Author:

Neha Chopde

Horticulture Section, College of

Agriculture, Amravati Road,

Nagpur, Maharashtra, India

\section{Evaluation of China aster varieties under Vidarbha conditions}

\author{
Shital Bhagve, VU Raut, Neha Chopde and VP Satar
}

DOI: https://doi.org/10.22271/chemi.2020.v8.i3e.9249

\begin{abstract}
An investigation on 'Evaluation of China aster varieties under Vidarbha conditions' was carried out at Satpuda Botanic Garden, College of Agriculture, Nagpur (Maharashtra, India) from October, 2016 to March, 2017 in randomised block design with 8 treatments comprising of eight varieties of China aster viz., $\mathrm{V}_{1}$ - Phule Ganesh White, $\mathrm{V}_{2}$ - Phule Ganesh Purple, $\mathrm{V}_{3}$ - Phule Ganesh Pink, $\mathrm{V}_{4}$ - Arka Shashank, $\mathrm{V}_{5}$ - Arka Kamini, $\mathrm{V}_{6}-$ Arka Poornima, $\mathrm{V}_{7}$ - Arka Aadhya and $\mathrm{V}_{8}-$ Arka Archana replicated thrice. The results of investigation revealed that, significantly maximum plant spread (East-West and North-South), stem diameter, flowering duration, number of flowers plant $^{-1}$, flower yield ha ${ }^{-1}$, diameter of flower and shelf life of flower were registered with the variety Phule Ganesh White followed by Phule Ganesh Purple, whereas, significantly earliest 50 per cent flowering was noticed with the variety Arka Archana. Significantly minimum disc diameter of flower was recorded with Phule Ganesh White.
\end{abstract}

Keywords: China aster, varieties, evaluation, growth, flower yield, quality

\section{Introduction}

China aster (Callistephus chinensis Nees) belongs to one of the largest families of flowering plants 'Asteraceae'. It is a free blooming half hardy, easy growing winter annual crop grown for cut flower as well as loose flower. The bloom type depends mainly upon the relative number of the two kinds of florets and their shapes. The most suitable character for the classification of China aster is the shape of ray florets. Among the traditional flowers China aster ranks next to chrysanthemum and marigold in importance. Though the flower yield and quality are primarily varietal characters, they are also greatly influenced by climatic factors, ultimately leading to variation in their performance. China aster is commercially grown by marginal and small farmers in Vidarbha (Maharashtra). China aster flower has a great demand in local market as cut flower and potted plants, previously it was grown with local varieties, but quality is not up to the mark as desired by the customers due to lacking of selection of varieties as well as improper use of agro-techniques. Although, there are sufficient number of cultivars under cultivation but their performance are region specific and varies from place to place, information on best China aster cultivar for loose flower production and cut flower production is lacking under the Vidarbha region of Maharashtra. Hence, the present investigation was undertaken with emphasis on selection of suitable varieties of China aster based on performance evaluation for Vidarbha (Maharashtra) zone particularly in Nagpur during winter season.

\section{Materials and Methods}

An investigation was carried out to evaluate different China aster varieties in respect of growth, flowering, yield and quality of flowers at Satpuda Botanic Garden, College of Agriculture, Nagpur (Maharashtra) from October, 2016 to March, 2017 in randomised block design with 8 treatments comprising of eight varieties of China aster viz., $\mathrm{V}_{1}$ - Phule Ganesh White, $V_{2}$ - Phule Ganesh Purple, $V_{3}$ - Phule Ganesh Pink, $V_{4}$ - Arka Shashank, $V_{5}$ - Arka Kamini, $\mathrm{V}_{6}-$ Arka Poornima, $\mathrm{V}_{7}-$ Arka Aadhya and $\mathrm{V}_{8}-$ Arka Archana replicated thrice. The plant material of different varieties of China aster was collected from IIHR, Bangalore (Karnataka) and NARP, Ganeshkhind, Pune (Maharashtra).

The experimental plot was brought to fine tilth by ploughing, clod crushing and harrowing. At the time of land preparation, well-rotted FYM @ $15 \mathrm{t} \mathrm{ha}^{-1}$ was mixed uniformly in the soil before last harrowing. 
The field was then laid out with flat beds of the dimension $1.50 \mathrm{~m} \times 2.40 \mathrm{~m}$. As per the treatment, uniform and healthy seedlings of eight varieties of aster were transplanted in the prepared plots at the spacing of $30 \mathrm{~cm} \times 30 \mathrm{~cm}$. Treatment wise half the dose of $100 \mathrm{~kg}$ nitrogen was applied in the form of urea before transplanting of seedlings and the remaining half dose of nitrogen was top dressed after 30 days of transplanting. However, the full dose of $50 \mathrm{~kg}$ phosphorus and $50 \mathrm{~kg}$ potassium $\mathrm{ha}^{-1}$ were applied in the form of single super phosphate and muriate of potash, respectively at the time of transplanting. All the cultural operations viz., weeding, irrigation, pest control etc. were carried out as and when required. Various observations on growth, flowering, yield and quality parameters viz., plant spread (East-West and North-South), stem diameter, flowering duration, days for 50 per cent flowering, number of flowers plant ${ }^{-1}$, flower yield ha 1 , diameter of flower, disc diameter and shelf life of flower were recorded at proper stages and the data was statistically analysed by the method suggested by Panse and Sukhatme $(1995)^{[4]}$

\section{Results and Discussion}

The data presented in Table 1 revealed that, different varieties of China aster had significant effect on all growth, flowering, yield and quality parameters.

The range for plant spread (E-W and N-S) among the cultivars was from 21.20 to $35.10 \mathrm{~cm}$ and 21.50 to $36.10 \mathrm{~cm}$, respectively. However, range for stem diameter of aster plant was from 0.75 to $0.92 \mathrm{~cm}$. Significantly maximum East-West and North-South plant spread $(35.10 \mathrm{~cm}$ and $36.10 \mathrm{~cm}$, respectively) was recorded with the China aster variety Phule Ganesh White which was statistically at par with Phule Ganesh Purple (33.90 and $35.80 \mathrm{~cm}$, respectively) and minimum East-west plant spread was recorded with the variety Arka Poornima $(21.20 \mathrm{~cm})$ and North-South plant spread was noted with Arka Shashank $(21.50 \mathrm{~cm})$. Whereas, stem diameter of plant was found significantly the highest with the variety Phule Ganesh White $(0.92 \mathrm{~cm})$ and it was closely followed by Phule Ganesh Purple $(0.83 \mathrm{~cm})$, whereas, minimum stem diameter was observed with Arka Shashank $(0.75 \mathrm{~cm})$. The plant spread and stem diameter are genetically controlled parameters. The significant differences in the plant growth parameters of China aster varieties might be attributed due to the differential genetic makeup and varied growth rate among the varieties of China aster. The better performance of variety Phule Ganesh White in respect of plant spread and stem diameter might be due to their genetic make-up and better adaptability to the prevailing environmental conditions. These results are in conformity with the results reported earlier in China aster by Zosiamliana et al. (2013) ${ }^{[7]}$ and Sankari et al. (2019) ${ }^{[5]}$.

In respect of flowering, significantly the earliest 50 per cent flowering was recorded with the variety Arka Archana (85.24 days) which was followed by Phule Ganesh Pink and Arka Aadhya (87.18 and 87.35 days, respectively), however, the 50 per cent flowering was found significantly late with the variety Phule Ganesh Purple (93.80 days). The different period required for the 50 per cent flowering in China aster varieties might be due to the varying growth rate and their different genetic make-up. Similar variation due to different varieties have also been observed by Naikwad et al. (2019) ${ }^{[3]}$ in China aster.

The range for flowering duration of aster among the cultivars was from 22.34 to 35.11 days. The blooming period was registered significantly highest with the variety Phule Ganesh White (35.11 days) and it was closely followed by Phule Ganesh Purple (32.99 days) and the lowest blooming period was noticed with the variety Arka Archana (22.34 days). However, in respect of flower yield and quality parameters like number of flowers plant ${ }^{-1}$ (35.00), flower yield ha ${ }^{-1}(13.20$ t) and diameter of flower $(7.26 \mathrm{~cm})$ were recorded maximum with the variety Phule Ganesh White which was closely followed by Phule Ganesh Purple (31.40, $12.42 \mathrm{t}$ and $7.12 \mathrm{~cm}$, respectively). Significantly the lowest disc diameter of flower $(1.08 \mathrm{~cm})$ was registered with variety Phule Ganesh White which was closely followed by Phule Ganesh Purple (1.57 $\mathrm{cm})$, whereas, the highest disc diameter was recorded with Arka Shashank $(2.96 \mathrm{~cm})$. Also, shelf life of loose flower of aster was registered significantly highest with the variety Phule Ganesh White (5.38 days) which was closely followed by Phule Ganesh Purple (5.32 days) and the lowest shelf life was noted with the variety Arka Kamini (3.65 days). The yield of aster flowers produced per plant might be directly related to production of maximum vegetative growth in respect of plant spread and stem diameter with good number of developed flower buds on the plant, thereby synthesis of more photosynthates resulted in production of highest yield of better quality flowers on the branches. Also the increased flower yield might be due to increased diameter of flower and number of flowers produced per plant. The similar results were obtained previously in China aster by Chavan et al. $(2010)^{[1]}$, Chowdhuri et al. (2016) ${ }^{[2]}$ and Zosiamliana et al. (2012) ${ }^{[6]}$.

Thus it can be inferred from the present investigation that, among the different varieties of China aster studied, variety Phule Ganesh White was found superior in respect of growth, flower yield as well as quality parameters under Vidarbha (M.S.) conditions.

Table 1: Comparative evaluation of China aster varieties under Vidarbha conditions during 2016-17

\begin{tabular}{|c|c|c|c|c|c|c|c|c|c|c|}
\hline \multirow[b]{2}{*}{ Treatments } & \multicolumn{2}{|c|}{ Plant spread $(\mathrm{cm})$} & \multirow{2}{*}{$\begin{array}{c}\text { Stem } \\
\text { diameter } \\
(\mathbf{c m})\end{array}$} & \multirow{2}{*}{\begin{tabular}{|c|} 
Days for 50 per \\
cent flowering \\
(days)
\end{tabular}} & \multirow{2}{*}{\begin{tabular}{|c|}
$\begin{array}{c}\text { Flowering } \\
\text { duration } \\
\text { (days) }\end{array}$ \\
\end{tabular}} & \multirow{2}{*}{$\begin{array}{c}\text { Number of } \\
\text { flowers plant }^{-1}\end{array}$} & \multirow{2}{*}{$\begin{array}{c}\text { Flower yield } \\
\text { ha }^{-1}(\mathbf{t})\end{array}$} & \multirow{2}{*}{$\begin{array}{c}\text { Diameter } \\
\text { of flower } \\
(\mathrm{cm})\end{array}$} & \multirow{2}{*}{$\begin{array}{c}\text { Disc } \\
\text { diameter } \\
(\mathrm{cm})\end{array}$} & \multirow{2}{*}{$\begin{array}{c}\text { Shelf life } \\
\text { (days) }\end{array}$} \\
\hline & E-W & N-S & & & & & & & & \\
\hline $\begin{array}{c}\mathrm{T}_{1}-\text { Phule } \\
\text { Ganesh White }\end{array}$ & 35.10 & 36.10 & 0.92 & 91.31 & 35.11 & 35.00 & 13.20 & 7.26 & 1.08 & 5.38 \\
\hline $\begin{array}{c}\mathrm{T}_{2} \text {-Phule } \\
\text { Ganesh Purple }\end{array}$ & 33.90 & 35.80 & 0.83 & 93.80 & 32.99 & 31.40 & 12.42 & 7.12 & 1.57 & 5.32 \\
\hline $\begin{array}{c}\mathrm{T}_{3} \text {-Phule } \\
\text { Ganesh Pink } \\
\end{array}$ & 25.20 & 31.30 & $\begin{array}{c}0.81 \\
81\end{array}$ & 87.18 & 26.19 & 27.73 & 11.24 & 6.64 & 2.20 & 4.96 \\
\hline $\begin{array}{c}\text { T4-Arka } \\
\text { Shashank }\end{array}$ & 22.30 & 21.50 & $\begin{array}{l}0.75 \\
0.75\end{array}$ & 90.56 & 31.27 & 25.77 & 9.94 & 5.88 & 2.96 & 4.76 \\
\hline $\begin{array}{l}\mathrm{T}_{5} \text {-Arka } \\
\text { Kamini }\end{array}$ & 29.10 & 23.20 & $\begin{array}{l}0.76 \\
0.76\end{array}$ & 89.19 & 27.35 & 20.50 & 9.91 & 5.44 & 1.90 & 3.65 \\
\hline $\begin{array}{c}\mathrm{T}_{6} \text {-Arka } \\
\text { Poornima }\end{array}$ & 21.20 & 24.10 & $\begin{array}{l}0.80 \\
0.80\end{array}$ & 88.39 & 26.39 & 24.93 & 8.25 & 6.53 & 1.59 & 3.97 \\
\hline
\end{tabular}




\begin{tabular}{|c|c|c|c|c|c|c|c|c|c|c|}
\hline $\begin{array}{c}\text { T7-Arka } \\
\text { Aadhya }\end{array}$ & 30.10 & 33.10 & $\begin{array}{c}0.79 \\
.92 \\
0.92\end{array}$ & 87.35 & 24.34 & 24.27 & 7.91 & 6.03 & 2.37 & 3.65 \\
\hline $\begin{array}{c}\text { T8-Arka } \\
\text { Archana }\end{array}$ & 33.40 & 35.20 & 0.82 & 85.24 & 22.34 & 27.00 & 9.19 & 7.08 & 2.36 & 4.61 \\
\hline F-test & Sig. & Sig. & Sig. & Sig. & Sig. & Sig. & Sig. & Sig. & Sig. & Sig. \\
\hline S.E (m) \pm & 0.57 & 0.49 & 0.02 & 0.31 & 0.35 & 0.51 & 0.20 & 0.16 & 0.06 & 0.14 \\
\hline C.D. at 5\% & 1.74 & 1.48 & 0.07 & 0.95 & 1.07 & 1.54 & 0.62 & 0.49 & 0.19 & 0.42 \\
\hline
\end{tabular}

\section{References}

1. Chavan MD, Jadhav PB, Rugge VC. Performance of China aster varieties and their response to different levels of nitrogen. Indian J Hort. 2010; 67:378-381.

2. Chowdhuri TK, Rout B, Sadhukhan R, Mondal T. Performance evaluation of different varieties China aster in Sub-Tropical Belt of West Bengal. Int. J. Pharma. Sci. Invention. 2016; 5(8):15-18.

3. Naikwad D, Kandpal K, Hugar A, Patil MG, Kulkarni V. Performance of different varieties of China aster for north eastern dry zone of Karnataka. J Pharmacogn. Phytochem. 2019; 8(4):1486-1494.

4. Panse VG, Sukhatme PV. Statistical Methods for Agricultural Workers. New Delhi, Publication and Information Division, ICAR, 1995.

5. Sankari A, Anand M, Kavitha M, Anita B. Per se performance of China aster varieties for yield under Nilgiris. Int. J. Chem. Studies. 2019; 7(3):1649-1652.

6. Zosiamliana JH, Reddy GSN, Rymbai H. Growth, flowering and yield characters of some cultivars of China aster (Callistephus chinensis Nees.). J Nat. Prod. Plant Resources. 2012; 2(2):302-305.

7. Zosiamliana JH, Reddy GSN, Rymbai H. Studies on performance of some varieties of China aster (Callistephus chinensis Nees.) in Andrha Pradesh. Prog. Hort. 2013; 45(2):312-316. 